УДК 330.101

\author{
Васильченко К.Г. \\ аспірант \\ кафедра економіки підприємництва \\ E-mail: k_vasil4enko@mail.ru \\ Херсонський національний технічний університет \\ Бериславське шосе, 24, м. Херсон, Україна, 73008
}

\title{
КЛЮЧОВІ НАПРЯМКИ ІННОВАЦІЙНОГО РОЗВИТКУ ПІДПРИЕМСТВ ХАРЧОВОЇ ПРОМИСЛОВОСТІ
}

\begin{abstract}
Визначено можливості і особливості виготовлення безпечної екологічно чистої продукції в Україні. Сформульовано вимоги до випуску продуктів харчових підприємств і перспективні напрями розвитку інноваційної діяльності з урахуванням стандартів якості.
\end{abstract}

Ключові слова: інноваційна діяльність, харчова промисловість, перспективні напрямки, ефективність.

Постановка проблеми та ії̈ зв'язок $з$ важливими науковими та практичними завданнями. Посилення вимог до якості і безпечності продуктів харчування $€$ міжнародною тенденцією, яка спричинена зростанням захворювань, пов'язаних з нездоровим способом життя та неякісним харчуванням. Найбільш перспективні напрями інноваційного розвитку підприємств харчової промисловості мають визначатися з урахуванням світових тенденцій розвитку галузі та попиту на окремі види інноваційної продукції. Це обумовлює актуальність статті, яка пропонується.

Аналіз останніх публікацій по проблемі [1-7] показує, що інноваційному розвитку підприємств харчової промисловості приділяється велика увага вітчизняних та зарубіжних вчених. Однак ця проблема багатогранна i потребує подальших досліджень.

Формулювання цілей дослідження. Метою дослідження $є$ визначення ключових напрямків інноваційного розвитку харчових підприємств з урахуванням сучасних тенденцій споживання продуктів харчування.

Виклад основних результатів та їх обгрунтування. Одним із найбільш перспективних напрямів інноваційного розвитку харчової промисловості є виробництво харчової продукції з екологічно чистої сировини. Згідно [1, с. 59] органічне сільське господарство - це виробнича система, яка підтримує родючість грунтів, добрий стан екосистем і здоров'я людей. Виробництво сільськогосподарської продукції за встановленими правилами дає змогу виробляти органічні продукти 3 оздоровчими якостями, а також зберігати та впроваджувати природні ресурси. Така продукція не містить хімічні речовини, антибіотики, консерванти, генно-модифіковані організми. Органічна продукція має бути вирощена без використання мінеральних і синтетичних добрив та без застосування засобів захисту рослин.
Розвиненні країни світу впроваджують свої стандарти якості, дотримання яких є обов'язковою умовою. В країнах СС Державні органи уповноважені здійснювати акредитацію приватних сертифікаційних установ i наглядів за їхньою діяльністю. Вони контролюють фермерські господарства, їх продукцію, спостерігають за імпортом з інших країн. В Україні ж спостерігається використання виробниками самостійно розроблених технічних умов замість стандартів якості [7, с. 42]. Проблема органічного сільського господарства сьогодні набуває великої уваги дослідників [1, 2, 4, 5, 7]. Підставою для цього служать природні умови держави.

В Україні близько 40\% території займають потенційно родючі чорноземні грунти. Зважаючи на досить високий вміст гумусу і суглинковий механічний склад, чорноземи забезпечують добру врожайність, особливо зернових та олійних культур при богарному землеробстві. Україна має певні переваги щодо можливостей, які пропонує збалансоване та органічне сільське господарство, низький рівень використання пестицидів і хімічних добрив, досить значну кількість малих ферм і робочої сили. Близьке сусідство з країнами СС - споживачами органічних продуктів робить Україну інвестиційно привабливою.

Висока мотивація інноваційного розвитку органічних продуктів харчування визначає готовність частини споживачів платити додаткову премію за якість і безпеку харчування. Перевищення вартості за органічні продукти по країнам ЄС складають 59\% для Австрії, 20-30\% для Данії, 35-40\% для Нідерландів, 35\% для Німеччини, 25-35\% для Франції, 30\% для Швейцарії. Середні щорічні темпи зростання ринку становлять 10-15\% [3]. Світовий ринок органічної продукції нині становить 50 млрд. дол. США. В Україні сучасний внутрішній споживчій ринок органічних продуктів становить 139 млн. дол. США, 


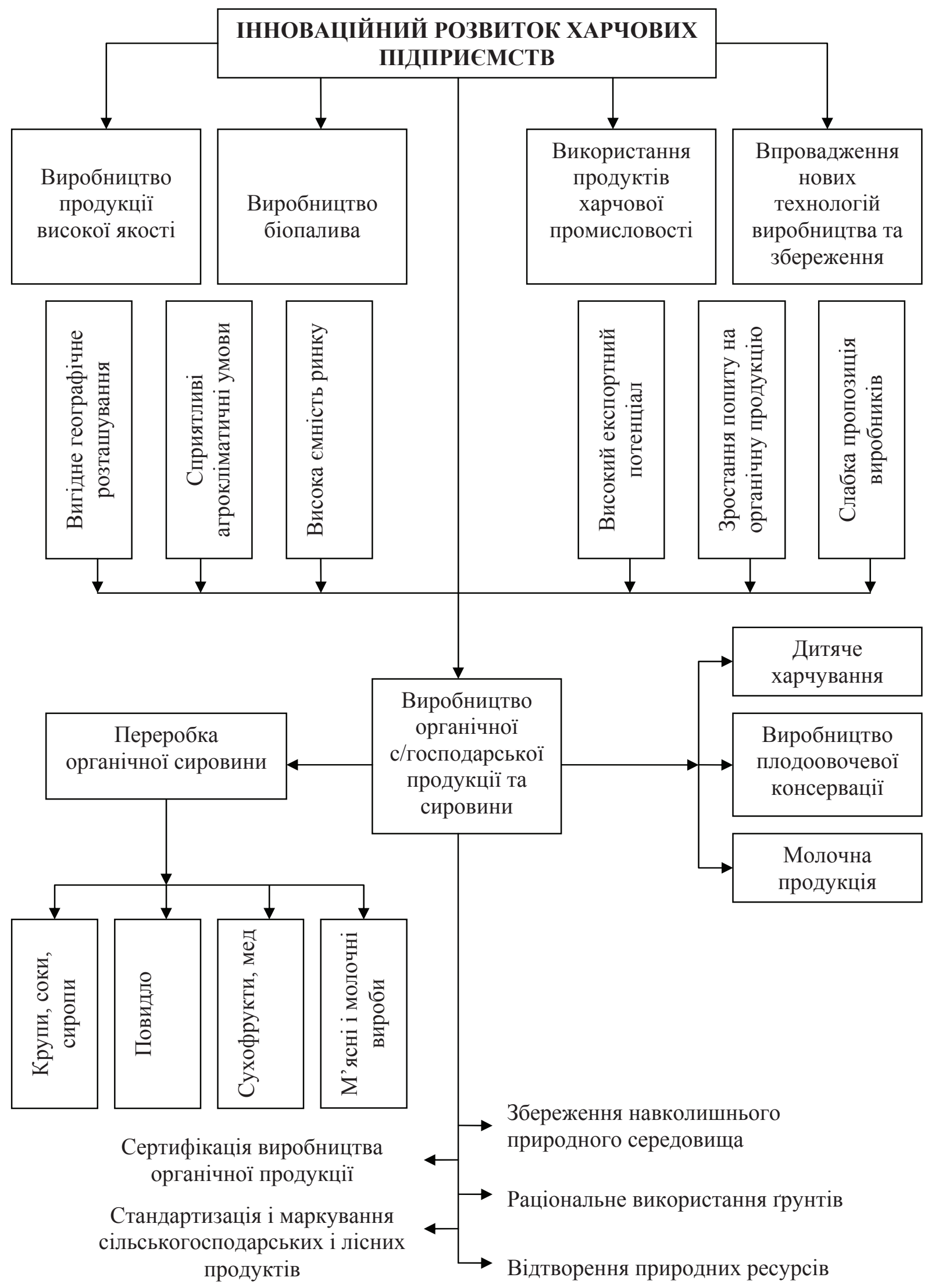

Рис. 1. Інноваційний розвиток харчових підприємств 
сертифіковані 121 виробник органічної сільськогосподарської продукції і 270,2 тис. га земель для зрощування органічної сировини.

Спостерігається тенденція наповнення внутрішнього ринку власною органічною продукцією за рахунок налагодження переробки органічної сировини. Інноваційними напрямками в цьому питанні є виробництво плодоовочевої консервації, дитячого харчування, молочної продукції. Основним ринком збуту органічних продуктів, виготовлених в Україні, є країни СС.

Рентабельність такого бізнесу по всьому світу суттєво залежить від рівня державної підтримки. В Україні поки ще не має законів, що регулюють цей ринок, хоча передумови для його розвитку реальні і здійсненні. Так у [1, с. 64] описана технологія плоскоріза замість плужної обробки, технологія механічної обробки для боротьби 3 бур'янами і шкідливими додаваннями рослин, використання агрозаходів, підбір культур при сівозміні.

Зростання попиту на органічну харчову продукцію зумовлене посиленням екологічних та соціальних складових економічного розвитку. До важливих ключових напрямів інноваційного розвитку харчових підприємств слід віднести використання відходів в якості біопалива.

Виробництво нерафінованого соняшникового масла неухильно зростає, забезпечуючи вагому частину товарного експорту в Україні. У процесі переробки сировини виходить велика кількість відходів у вигляді соняшникового лушпиння і макухи, які можуть бути використанні в якості енергетичного ресурсу, як у необробленому вигляді, так і у вигляді пелет і гранул.

Біоенергетика вважається найбільш перспективним видом нетрадиційних і поновлюваних джерел енергії. Позитивним моментом цього напряму інноваційної діяльності харчових підприємств $є$ отримання прибутку від реалізації відходів та суміжної продукції.

Ще одним перспективним напрямком інноваційного розвитку підприємств харчової промисловості є виробництво біоетанолу високооктанової кисневмісної добавки до бензинів у виготовленні палива. Виробництво підакцизного спирту і паливного етанолу здійснюється на тих самих підприємствах і виробничих площах нафтопереробних підприємств, які мають усі стадії технологічного процесу 3 виробництва нафтопродуктів, i державних спиртових заводах [6, с. 89]. Це є загальним позитивним моментом впровадження такої технологічної інновації.

Економічна зацікавленість нафтопереробних заводів у виробництві бензинових сумішей виявляється і в тому, що біоетанол виведений з групи товарів, виробництво та обіг яких підлягає акцизному регулюванню. Це дозволяє виробникам усіх форм власності виготовити паливний біоетанол. Біодизель в два рази дешевше солярки, яка виробляється 3 нафти.

Розроблена на основі викладених міркувань схема ключових напрямів інноваційної діяльності харчових підприємств представлена на рис. 1.

Сировиною для виробництва біоетанолу є зерно, яке технологічно переробляється для виготовлення білка і жиру з виділенням крохмальних частин. $€$ розробки 3 використання для цього кукурудзи. Ці продукти переробки зерна можуть бути використані і в харчовій промисловості.

Динаміка інноваційних зрушень в харчовій промисловості України є позитивною, не зважаючи на недостатньо високі темпи здійснення інноваційних перетворень [7, с. 39].

За наявності державної підтримки можна забезпечити умови зростання зернового виробництва для експорту, особливо в депресивних регіонах, що є важливим елементом економічної, продовольчої та екологічної безпеки держави. Реалізація програм розвитку та заходів повинна відбуватися шляхом консолідації фінансових можливостей державного і місцевих бюджетів, коштів зацікавлених підприємств і організацій, а також грантів міжнародних асоціацій.

Висновки. Ключовими напрямками інноваційного розвитку підприємств харчової промисловості є виробництво високої якості та безпечності, розвиток виробництва органічної продукції, продукції поглибленої переробки з екологічно чистої сировини, а також біопалива 3 продуктів та відходів харчової промисловості.

\section{Література}

1. Потапенко В. Г. Органічне сільське господарство як чинник економічної безпеки / В. Г. Потапенко, О. М. Потапенко // Економіка АПК. - 2011. - № 5. - С. 58-65.

2. Коваленко К. С. Шляхи вирішення проблем конкурентоспроможності вітчизняних підприємств харчових продуктів на міжнародному ринку / К. С. Коваленко // Інноваційна економіка. - 2012. - № 7. - С. 118-121.

3. International Federation of Organic Agriculture Movements. The Prinsiples of Organic Agriculture. [Електронний ресурс] - Режим доступу: http://www.inform.org/about inform/pdfs/POA folder russian.pdf

4. Вовк В. Сертификация органического сельского хозяйства в Украине: современное состояние, перспективы, стратегия на будущее / В. Вовк // АПК-информ. [Электронный ресурс] - Режим доступа: http://www.lol.org.ua/rus/showart.php?id=15634.

5. Крисанов Д. Ф. Трансформації в харчових галузях та їх інноваційно-технологічна модифікація / Д. Ф. Крисанов, К. О. Бужинська // Економіка АПК. - 2010. - № 7. - С. 113-121. 
6. Майданевич П. М. Виробництво біоетанолу - перспективний шлях розвитку підприємств спиртової галузі АПК / П. М. Майданевич // Актуальні проблеми економіки. - 2010. - № 1. - С. 88-92.

7. Інноваційний розвиток промисловості як складова структурної трансформації економіки України. - К. : НІСД. - 2013. $71 \mathrm{c}$.

Стаття надійшла 17.09.2014

Рецензент: Шарко М.В., доктор економічних наук, професор кафедри економіки підприємництва Херсонського національного технічного університету

\author{
Васильченко Е.Г. \\ аспирант \\ кафедра экономики предпринимательства \\ E-mail: k_vasil4enko@mail.ru \\ Херсонский национальный технический университет \\ Бериславское шоссе, 24, г. Херсон, Украина, 73008
}

\title{
КЛЮЧЕВЫЕ НАПРАВЛЕНИЯ ИННОВАЦИОННОГО РАЗВИТИЯ ПРЕДПРИЯТИЙ ПИЩЕВОЙ ПРОМЫШЛЕННОСТИ
}

Определены возможности и особенности изготовления безопасной экологически чистой продукции в Украине. Сформулированы требования к выпуску продуктов пищевых предприятий и перспективные направления развития инновационной деятельности с учетом стандартов качества.

Ключевые слова: инновационная деятельность, пищевая промышленность, направления развития, эффективность.

\author{
Vasilchenko E.G. \\ Postgraduate student \\ Department of Economics of Entrepreneurship \\ k_vasil4enko@mail.ru \\ Kherson National Technical University \\ Ostrovsky Lane, 17 b, Kherson, Ukraine, 73000
}

\section{KEY DIRECTIONS OF INNOVATIVE DEVELOPMENT OF FOOD INDUSTRY ENTERPRISES}

\begin{abstract}
Possibilities and features of making of safe environmentally clean products in Ukraine are determined. Requirements of production of food enterprises products and prospects of directions of innovative activity development that takes to the account standards of quality are formulated. The most perspective directions of innovative development of food industry enterprises are determined with taking to the account world tendencies of development of this branch and demand for separate kinds of innovative products.

Key directions of innovative developments of food industry enterprises are productions of high quality and security, development of production of organic goods, products of the deep processing from nonpolluting raw material and also biofuel from products and wastes of food industry.

Keywords: innovative activity, food industry, development direction, effectiveness.
\end{abstract}

\section{References}

1. Potapenko V. H., Potapenko O. M. (2011). Orhanichne silske hospodarstvo, yak chynnyk ekonomichnoi bezpeky. Ekonomika APK, $5,58-65$.

2. Kovalenko K. S. (2012). Shliakhy vyrishennia problem konkurentospromozhnosti vitchyznianykh pidpryiemstv kharchovykh produktiv na mizhnarodnomu rynku. Innovatsiina ekonomika, 7, 118-121.

3. International Federation of Organic Agriculture Movements. The Prinsiples of Organic Agriculture. [Elektronnyi resurs] - Rezhym dostupu: http://www.inform.org/about inform/pdfs/POA_folder russian.pdf

4. Vovk V. Sertyfykatsyia orhanycheskoho selskoho khoziaistva v Ukrayne: sovremennoe sostoianye, perspektyvu, stratehyia na budushchee. APK-inform [Elektronnyi resurs] - Rezhym dostupu : http://www.lol.org.ua/rus/showart.php?id=15634.

5. Krysanov D. F., Buzhynska K. O. (2010). Transformatsii v kharchovykh haluziakh ta yikh innovatsiino-tekhnolohichna modyfikatsiia. Ekonomika APK,7, 113-121.

6. Maidanevych P. M. (2010). Vyrobnytstvo bioetanolu - perspektyvnyi shliakh rozvytku pidpryiemstv spyrtovoi haluzi APK. Aktualni problemy ekonomiky, 1, 88-92.

7. Innovatsiinyi rozvytok promyslovosti yak skladova strukturnoi transformatsii ekonomiky Ukrainy. - K.: NISD, $2013,71$. 